\title{
ETIOLOGY OF BACTERIAL MENINGITIS AMONG CHILDREN AGED 2-59 MONTHS IN SALVADOR, NORTHEAST BRAZIL, BEFORE AND AFTER ROUTINE USE OF HAEMOPHILUS INFLUENZAE TYPE B VACCINE
}

\author{
Cristiana M. Nascimento-Carvalho ${ }^{1}$, Otávio A. Moreno-Carvalho²
}

\begin{abstract}
Objective: To describe the frequency of etiologic agents of bacterial meningitis (BM) among children aged 2-59 months in a sample of patients in Salvador, Northeast Brazil, with emphasis on the frequency of BM of unknown etiology (BMUE), just before, during and after the implementation of routine immunization of infants with Haemophilus influenzae type $b$ (Hib) vaccination. Method: Demographic, clinical and cerebrospinal fluid (CSF) information was collected from the chart of every patient, aged 2-59 months, whose CSF exam was performed at the CSF Lab - José Silveira Foundation, between January 1989 and December 2001. Every CSF exam was completely performed according to standard methods. The etiologic diagnosis was based on either culture and/or latex-agglutination test. When the agent was only seen on Gram stained smear, the diagnosis was descriptive. BMUE was defined as: glucose $\leq 40 \mathrm{mg} / \mathrm{dl}$, protein $\geq 100 \mathrm{mg} / \mathrm{dl}$, white blood cell count $\geq 20$ cells $/ \mathrm{mm}^{3}$, percentage of neutrophils $\geq$ 80\%. Results: Of 1519 patients, 894 (58.9\%) had normal exams and BM was diagnosed in 95 (6.2\%). Etiologic agents were: Hib $(44.2 \%)$, meningococcus (13.7\%), Gram-negative bacilli (11.6\%), Mycobacterium tuberculosis (6.3\%), pneumococcus (4.2\%), other agents (4.2\%); BMUE was diagnosed in $15.8 \%$ of cases with BM. By analysing the frequency of BMUE and Hib among all exams performed yearly, the peaks were recorded in $1989(5.3 \%)$ and 1990 (16.9\%), respectively, decreasing to $0.7 \%$ and $0 \%$ in 2001 . Conclusion: It is possible that the implementation of the conjugate Hib vaccine during the 1990's has been decreasing not only the occurrence of Hib meningitis but also of BMUE.
\end{abstract}

KEYWORDS: meningitis, childhood, Haemophilus influenzae type b, immunization, cerebrospinal fluid, bacterial meningitis of unknown etiology.

\begin{abstract}
Etiologia da meningite bacteriana em crianças com idade entre 2 e 59 meses em Salvador, Nordeste do Brasil, antes e depois do uso rotineiro da vacina para Haemophilus influenzae tipo b.

RESUMO - Objetivo: Descrever a freqüência dos agentes etiológicos de meningite bacteriana (MB) em amostra das crianças com idade entre 2 e 59 meses, em Salvador, Nordeste do Brasil, com ênfase na freqüência de MB de etiologia indeterminada (MBEI), antes, durante e após a implementação da imunização rotineira de lactentes com vacina para Haemophilus influenzae tipo b (Hib). Método:Variáveis demográficas, clínicas e liquóricas (LCR) foram coletadas da ficha de cada paciente com idade entre 2 e 59 meses, cujo exame de LCR foi realizado no Laboratório de LCR - Fundação J osé Silveira, entre janeiro de 1989 e dezembro de 2001. Cada exame de LCR foi realizado por completo conforme os métodos padronizados. 0 diagnóstico etiológico foi baseado ou em cultura e ou teste de aglutinação em látex. Quando 0 agente foi identificado apenas no GRAM , 0 diagnóstico foi descritivo. M BEl foi definida como glicose $\leq 40 \mathrm{mg} / \mathrm{dl}$, proteína $\geq 100 \mathrm{mg} / \mathrm{dl}$, celularidade global $\geq 20$ células $/ \mathrm{mm}^{3}$ e percentual de neutrófilos $\geq 80 \%$. Resultados: Dos 1519 pacientes, 894 (58,9\%) tiveram exames normais e MB foi diagnosticada em 95 (6,2\%). Os agentes etiológicos foram: Hib (44,2\%), meningococo (13,7\%), bacilos Gram-negativos (11,6\%), Mycobacterium tuberculosis $(6,3 \%)$, pneumococo $(4,2 \%)$, outros agentes (4,2\%); M BEl foi diagnosticada em $15,8 \%$ dos casos de M B. Ao analisar a frequêencia da M BEl e por Hib entre todos os exames realizados a cada ano, os picos foram registrados em 1989 (5,3\%) e 1990 (16,9\%), respectivamente, diminuindo para 0,7\% e 0\% em 2001. Conclusão: É possível que a implementação do uso da vacina conjugada para Hib durante a década de 1990 tenha decrescido não apenas a ocorrência da meningite por Hib mas também a MBEI.
\end{abstract}

PALAVRAS-CHAVE: meningite, criança, Haemophilus influenzae tipo b, imunização, líquor, meningite bacteriana de etiologia indeterminada. ${ }^{1} M D$, PhD, Adjunct Professor, Department of Pediatrics, Faculty of Medicine, Federal University of Bahia; ${ }^{2}$ M D, Cerebrospinal Fluid Specialist, CSF Lab, José Silveira
Foundation, Salvador BA, Brazil.

Received 9 June 2003, received in final form 24 October 2003. Accepted 21 November 2003.

Dra. Cristiana Nascimento-Carvalho - Rua Prof. Aristides Novis 105/1201B - 40210-630 Salvador BA - Brazil.

E-mail: nascimentocarvalho@hotmail.com 
Bacterial meningitis (BM) is one of the most potentially serious infections in infants and older children because it is associated with a high rate of acute complications, risk of chronic morbidity and death ${ }^{1}$. Beyond the neonatal period, the main agents of BM are Haemophilus influenzae type $b(\mathrm{Hib})$, meningococcus and pneumococcus, being the reported mortality $7.7 \%, 3.5 \%$ and $30 \%$, respectively ${ }^{2}$. The most dramatic change in the epidemiology of $\mathrm{BM}$, besides the advent of antibiotics, had occurred in the 1990's because of licensure of conjugate vaccines against Hib which contributed to the conspicuous decrease in the incidence of Hib meningitis ${ }^{3}$.

Before the widespread use of Hib conjugate vaccines, approximately $70 \%$ of cases of BM among children younger than 5 years were due to $\mathrm{Hib}^{1}$ and the routine use of Hib conjugate vaccine has lead to a $94 \%$ reduction in the number of cases of Hib meningitis ${ }^{4}$. The median age of BM in the United States increased from age 15 months in 1986 to 25 years in 1995 , being meningitis usually due to meningococcus or pneumococcus 4 .

The purpose of this research is to describe the frequency of etiologic agents of BM among children aged 2-59 months in a sample of patients in Salvador, Northeast Brazil, with emphasis on the frequency of BM of unknown etiology (BMUE), just before, during and after the implementation of routine immunization of infants with Hib vaccination.

\section{METHOD}

The charts of all patients whose cerebrospinal fluid (CSF) exam was performed at the CSF Lab, J osé Silveira Foundation, Salvador, Brazil, between January 1989 and December 2001, were reviewed. Those patients aged 2-59 months were identified and demographic, clinical and CSF information was collected from the chart to the study questionnaire. The CSF examination was performed by the same person (OAMC), at the same Lab and included, in all samples: CSF white blood cell (WBC) and differential cell counts, concentration of protein, glucose, chloride, AST (glutamic-oxaloacetic transaminase) and LDH (lactate dehydrogenase), bacteriologic and mycologic exams that included cultures for aerobic bacteria, fungus and Mycobacterium tuberculosis, specific stained-smears (Gram, Ziehl-Nielsen) and latexagglutination tests. The etiologic diagnosis was based on either culture and/or latex-agglutination test. When the agent was only seen on Gram stained smear, the diagnosis was descriptive. BM UE was defined as: glucose $\leq 40 \mathrm{mg} / \mathrm{dl}$, protein $\geq 100 \mathrm{mg} / \mathrm{dl}$, WBC count $\geq 20$ cells $/ \mathrm{mm}^{3}$, percentage of neutrophils $\geq 80 \%{ }^{5}$

Statistical analysis were performed by using the Statistical Package for the Social Sciences (SPSS 9.0) and were descriptive. The annual frequency of the main etiologic agents and of BMUE was calculated by computing the total number of exams performed each year as the denominator. Comparison of annual frequency was assessed by two tailed Fisher's exact test with a significance level of 0.05 .

\section{RESULTS}

Of 1519 patients, 894 (58.9\%) had normal exams and BM was diagnosed in 95 (6.2\%). Etiologic agents were: Hib $(44.2 \%)$, meningococcus $(13.7 \%)$, Gram-negative bacilli $(11.6 \%)$, M. tuberculosis $(6.3 \%)$, pneumococcus $(4.2 \%)$, staphy-

Table 1. Annual frequency of etiologic agents of bacterial meningitis in a sample of children aged 2-59 months, in Salvador, Northeast Brazil, 19892001.

\begin{tabular}{|c|c|c|c|c|c|c|}
\hline Year & Total & Hib* & M eningococcus* & Pneumococcus* & $\begin{array}{c}\text { Less Frequent } \\
\text { Agents* } \dagger\end{array}$ & BMUE* \\
\hline 89 & 38 & $2(5.3)$ & $1(2.6)$ & 0 & $2(5.3)$ & $2(5.3)$ \\
\hline 90 & 59 & $10(16.9)$ & 0 & 0 & $2(3.4)$ & $1(1.7)$ \\
\hline 91 & 73 & $3(4.1)$ & $1(1.4)$ & $1(1.4)$ & 0 & $1(1.4)$ \\
\hline 92 & 73 & $6(8.2)$ & $2(2.7)$ & $1(1.4)$ & 0 & $1(1.4)$ \\
\hline 93 & 115 & $6(5.2)$ & $4(3.5)$ & 0 & $1(0.9)$ & $1(0.9)$ \\
\hline 94 & 116 & $3(2.6)$ & 0 & $1(0.9)$ & $1(0.9)$ & $2(1.7)$ \\
\hline 95 & 106 & $1(0.9)$ & 0 & 0 & 0 & $1(0.9)$ \\
\hline 96 & 92 & $2(2.2)$ & $2(2.2)$ & $1(1.1)$ & 0 & 0 \\
\hline 97 & 88 & $1(1.1)$ & 0 & 0 & $1(1.1)$ & $1(1.1)$ \\
\hline 98 & 104 & $3(2.9)$ & $1(1.0)$ & 0 & $2(1.9)$ & 0 \\
\hline 99 & 148 & $2(1.4)$ & $1(0.7)$ & 0 & $3(2.0)$ & $2(1.4)$ \\
\hline 00 & 218 & $3(1.4)$ & 0 & 0 & $2(0.9)$ & $1(0.5)$ \\
\hline 1 & 289 & 0 & $1(0.3)$ & 0 & $7(2.4)$ & $2(0.7)$ \\
\hline
\end{tabular}

* Results in $n(\%)$, † Gram-negative bacilli, M. tuberculosis, staphylococcus, Hib, Haemophilus influenzae type b; BMUE, bacterial meningitis of unknown etiology. 
lococcus (4.2\%). BMUE was diagnosed in 15 (15.8\%) out of the cases with BM. Table 1 shows the annual frequency of the main etiologic agents and of BMUE. Comparison of frequency of Hib and BMUE during 1989 and 2001 showed $p=0.01$ and $p=0.07$, respectively.

\section{DISCUSSION}

The foregoing data presents Hib as the main etiologic agent of BM in children under five years of age. Although the conjugate Hib vaccine had been licensed in the United States in December $1990^{6}$, the massive use of this vaccine in Brazil at public health was initiated in 1999, as well as in other Latin America countries ${ }^{7}$. Between 1991 and 1999, the use of this vaccine had been done progressively in private settings. By analysing the data shown in Table 1, it is possible to observe a trend to decline in Hib annual frequency as of 1994. Patients whose CSF exams are performed at the CSF Lab, José Silveira Foundation, usually have private health insurance and have probably received Hib conjugate vaccine before 1999.

From the data shown in Table 1, it is also possible to observe a slight trend to decline in BMUE annual frequency. The diagnosis of BMUE is presumptive and based on non-specific CSF findings when there is no identified etiologic agent. Any bacterium that causes BM may presumptively causes BMUE. The impossibility of establishing a definitive etiologic diagnosis may be due to several factors as the inoculated size or the previous use of antimicrobial drugs. Therefore, some cases of BMUE may also be due to Hib infection. The decreasing trend of the annual frequency of BMUE may have been influenced by the implementation of the conjugate Hib vaccination. However, the sample size in this study is too small in order to study an association of Hib vaccination with the decline of BMUE frequency. In addition to that, the patients included in this study constitute a sample from the population of Salvador. Therefore, a population-based study is highly recommended in order to study this issue.

It is possible that the implementation of the conjugate $\mathrm{Hib}$ vaccine during the 1990's has been decreasing not only the occurrence of Hib meningitis but also of BMUE. A populationbased study is recommended in order to clarify this issue as is recommended the maintenance of surveillance over BM in

spite of the use of conjugate vaccines.

\section{REFERENCES}

1. Prober CG. Acute bacterial meningitis beyond the neonatal period. In Behrman RE, Kliegman RM, Jenson HB, (eds). Nelson textbook of pediatrics 16th ed. Philadelphia: Saunders, 2000:751-757.

2. Davey PG, Cruikshank JK, McManus IC, Mahood B, Snow MH, Gedd AM. Bacterial meningitis: Ten years' experience. J Hyg 1982;88:383-401.

3. Progress toward eliminating of Haemophilus influenzae type b disease among infants and children - United States, 1987-1997. MMWR Morb Mortal Wkly Rep 1998;47:993-998.

4. Schuchat A, Robinson K, Wenger JD, et al. Bacterial meningitis in the United States in 1995. Active Surveillance Team. N Engl J Med 1997;337:970-976.

5. Tunkel AR, Scheld WM. Acute meningitis. In Mandell GL, Bennett JE, Dolin R, (eds). Mandell, Douglas, and Bennett's principles and practice of infectious diseases 5 th $\mathrm{ed}$. Philadelphia: Churchill Livingstone, 2000:975-976

6. American Academy of Pediatrics Committee on Infectious Diseases: Haemophilus influenzae type b conjugate vaccines: recomendations for immunization of infants and children 2 months of age and older: update. Pediatrics 1991;88:169-172

7.Landaverde M, Di Fabio JL, Ruocco G, Leal I, Quadros C. Introducción de la vacuna conjugada contra Hib en Chile y Uruguay. Rev Panam Salud Publica 1999;5:200-206 